\title{
The impact of inflammation and immune activation on B cell differentiation during HIV-1 infection
}

\author{
Nicolas Ruffin ${ }^{1}$, Pham Hong Thang ${ }^{1,2}$, Bence Rethi ${ }^{1}$, Anna Nilsson ${ }^{1,3}$ and Francesca Chiodi ${ }^{1}$ * \\ ${ }^{1}$ Department of Microbiology, Tumor and Cell Biology, Karolinska Institutet, Stockholm, Sweden \\ 2 Department of HIV/AIDS, National Institute of Hygiene and Epidemiology, Hanoi, Vietnam \\ ${ }^{3}$ Department of Women's and Children's Health, Karolinska Institutet, Stockholm, Sweden
}

Edited by:

Frank Kirchhoff, University Clinic UIm, Germany

\section{Reviewed by:}

Jan Muench, Ulm University,

Germany

Michael Schindler, Helmholtz Zentrum

München, Germany

Andrea Cossarizza, University of

Modena and Reggio Emilia, Italy

*Correspondence:

Francesca Chiodi, Department of Microbiology, Tumor and Cell Biology,

Karolinska Institutet, Nobelsväg 16,

S-17177 Stockholm, Sweden.

e-mail: francesca.chiodi@ki.se
One important pathogenic feature of human immunodeficiency virus (HIV)-1 infection is chronic immune activation and impaired survival of T and B cells. A decline of resting memory B cells was reported to occur in both children and adults infected with HIV-1; these cells are responsible for maintaining an adequate serological response to antigens previously encountered in life through natural infection or vaccination. Further understanding of the mechanisms leading to impaired $B$ cell differentiation and germinal center reaction might be essential to design new HIV vaccines and therapies that could improve humoral immune responses in HIV-1 infected individuals. In the present article we summarize the literature and present our view on critical mechanisms of B cell development impaired during HIV-1 infection. We also discuss the impact of microbial translocation, a driving force for persistent inflammation during HIV-1 infection, on survival of terminally differentiated $B$ cells and how the altered expression of cytokines/chemokines pivotal for communication between $T$ and $B$ cells in lymphoid tissues may impair formation of memory $B$ cells.

\section{INTRODUCTION}

Human immunodeficiency virus (HIV)-1 infection is accompanied by weakened humoral responses to pathogens and vaccination antigens, which are not fully restored upon anti-retroviral therapy (ART; Titanji et al., 2006; Cagigi et al., 2010; Geretti and Doyle, 2010). Adaptive immunity has the unique capacity to confer memory to the immune system, leading to faster and stronger responses to recall antigens; memory B cells and plasma cells (PCs), leaving in specialized niches within the spleen and bone marrow (BM) are responsible for antibody secretion several years after vaccination and natural infections (Lanzavecchia and Sallusto, 2009).

Early studies showed an abnormal activation of B cells isolated from HIV-1 infected patients, resulting in increased concentration of circulating immunoglobulin $\mathrm{G}(\operatorname{IgG})$, a phenomenon known as hypergammaglobulinemia (Lane et al., 1983). Peripheral blood B cells from HIV-1 infected individuals are also susceptible to apoptosis (Muro-Cacho et al., 1995; Samuelsson et al., 1997) and show signs of exhaustion (Moir et al., 2001, 2008). In the lymphoid compartment of HIV-1 infected patients, accumulation of PCs was observed (Macias et al., 2001; Alos et al., 2005), possibly also accounting for hypergammaglobulinemia measured in serum. A role for HIV-1 virion and proteins in B cell activation has been envisaged. The HIV-1 protein gp120 was also shown to bind to tonsilar and splenic B cells and led to their polyclonal activation ( $\mathrm{He}$ et al., 2006). Nef appears to mediate multiple and opposite functions. Nef protein expressed on infected macrophages may lead to production of ferritin, which in turn promoted activation of B cells (Swingler et al., 2008). However it has also been shown that Nef suppresses immunoglobulin class-switch DNA recombination through blocking of CD154 pathway (Qiao et al., 2006).
Human immunodeficiency virus-1 infected patients retain the ability to generate HIV-1 specific memory B cells with mutated immunoglobulins (Scheid et al., 2009), suggesting that somatic hypermutation still occurs at early stage of the disease. Nevertheless, it has been questioned whether long-lived PCs could be established in HIV-1 infected patients (Lewis, 2010; Mascola and Montefiori, 2010). Indeed, despite high levels of circulating immunoglobulins (Lane et al., 1983), HIV-1 infected patients have a reduced number of $\mathrm{CD} 27+$ classical memory $\mathrm{B}$ cells in blood and reduced levels of long-term serological memory, defined as circulating antibodies to previously encountered pathogens and vaccine antigens (Titanji et al., 2006; Cagigi et al., 2010; Chiodi, 2010). Data from vaccination studies show that early antibody responses are similar in healthy individuals and HIV-1 infected patients (Ho et al., 2011). However, several months after vaccination, the levels of specific antibodies are decreased in patients (Pariani et al., 2011), suggesting either a defective generation or survival of memory B cells and PCs. Additionally, a recent study demonstrated that the levels of total immunoglobulins and HIV-1 neutralizing antibodies are affected by Rituximab treatment, an anti-CD20 monoclonal antibody which leads to depletion of memory B cells but not long-lived PCs lacking CD20 expression (Huang et al., 2010). Hypergammaglobulinemia disappeared transiently following $B$ cell depletion and loss of anti-HIV antibodies was associated with an increase in viral load in this HIV-1 untreated patient. The effect of Rituximab treatment on the level of non-neutralizing HIV antibodies was not discussed (Huang et al., 2010).

Altogether, these results support the possibility that high levels of immunoglobulins could preferentially arise from activated memory B cells and strengthen the hypothesis on the impaired 
differentiation of long-lived PCs during HIV-1 infection, as a consequence of deficient GC formation. The elucidation of signaling pathways involved in GC formation upon physiological conditions has just begun. Fragmentary knowledge is available on how HIV-1 infection perturbs B cell differentiation and GC formation. This perspective article will focus herein on signaling pathways important for B cell differentiation and GC formation that could be altered during HIV-1 infection and represent the underlying mechanisms for $\mathrm{B}$ cell dysfunctions in patients. The processes of microbial translocation and associated inflammation, taking place during acute and chronic phases of HIV-1 infection (Miedema, 2011), may strongly influence B cell homeostasis and effector functions.

\section{IMPAIRED SEROLOGICAL MEMORY DURING HIV-1: INSIGHT IN THE GC REACTION}

Memory B cells originate from GC-dependent or independent pathways (Berkowska et al., 2011). The canonical pathway involves the formation of GC in secondary lymphoid organs. Activated B cells, known as centroblasts, need to encounter antigen-presenting cells [dendritic cells, macrophage, follicular dendritic cells (FDC)] and $\mathrm{T}$ follicular helper ( $\mathrm{Tfh}$ ) cells to receive appropriate signals. Cell to cell contact, as well as chemokines and cytokines are essential for expansion, selection, and differentiation of Ag-specific B cell clones to memory B cells or long-lived PCs (Nutt and Tarlinton, 2011). The differentiation of B cells during HIV-1 infection may profoundly be affected by $\mathrm{T}$ cell depletion, cytokine, and chemokine alterations (Figure 1) as summarized in the following paragraphs.

\section{LYMPHOID TISSUE ARCHITECTURE AND T CELL HOMEOSTASIS}

The lymphoid tissue is organized to allow the encounter of immune cells with antigens under the regulatory effect of cytokines and growth factors. Comprising the vast majority of CD4+ T cells, lymphoid tissue is the place for high HIV-1 replication; as results of HIV-1 replication and inflammation, infiltration of effector $T$ cells into the lymph nodes takes place, followed by chronic immune activation, which is one of the hallmark of HIV-1 pathogenesis (Lederman and Margolis, 2008; Van Grevenynghe et al., 2008). Morphological studies of lymphoid tissues revealed sustained $\mathrm{T}$ cell depletion, lack of lymphoid follicles, and accumulation of PCs in a majority of patients naïve to treatment (Macias et al., 2001; Alos et al., 2005). ART, by reducing viral replication, leads to an increase, but not to normalization, of CD4+ T cells, and the partial restoration of small GCs, although with scarce B cell and FDC network. The sustained T cell depletion observed in some patients under ART was associated with collagen deposition in lymphoid tissues; this lymphatic tissue fibrosis greatly affects the lymph node architecture (Estes et al., 2008) and possibly also cells and molecular pathways involved in B cell maturation. Recently, it was shown that lymphopenia itself can impact maintenance of fibroblastic reticular cell (FRC) network as these cells require lymphotoxin- $\beta$, a cytokine available at lower concentrations as T cells are depleted. Since FRCs produce the cytokine IL-7, an essential survival factor for peripheral $\mathrm{T}$ cells, the loss of these cells can lead to a further decrease in T cell maintenance (Zeng et al., 2011). Loss of lymphoid tissue FRC network and associated fibrosis might lead to an irreversible damage in lymphoid tissue architecture that could limit immune regenerative therapies.

\section{ALTERED CHEMOKINE EXPRESSION DURING HIV-1 INFECTION}

The organization of lymphoid tissues into $\mathrm{B}$ and $\mathrm{T}$ cell zones is regulated through the expression of chemokines and chemokinereceptors. CD4+ helper T cells, after their priming by DCs, can increase their CXCR5 expression and migrate toward the $\mathrm{B}$ cell zone. Further signals from B cells are needed for the CD4+ helper T cell to fully acquire a Tfh cell phenotype and migrate into the GC. Similarly, upon antigen stimulation, CCR7 expression is increased on B cells, which consequently migrate to the border of $\mathrm{T}$ cell zone to get $\mathrm{T}$ cell help (Nutt and Tarlinton, 2011).

$\mathrm{T}$ follicular helper cells are crucial for GC formation and for B cell responses (Nutt and Tarlinton, 2011). In a recent paper, Tfh cells were shown to be more susceptible to simian immunodeficiency virus (SIV) infection in vivo (Klatt et al., 2011) than other CD4+ T cell subsets. The increased number of PCs observed in lymphoid tissues of HIV-1 infected patients may also lead to Tfh cell defects as a role of PCs in inhibiting Tfh cell functions was described (Pelletier et al., 2010). It remains essential to establish to which extent Tfh cells are affected in vivo during HIV-1 infection, as their altered functions could explain the dysregulations of GC reaction observed in patients. We previously showed that CXCR5 expression is altered on B cells from HIV-1 infected patients, which together with increased levels of circulating CXCL13, the ligand for CXCR5, might lead to impaired follicular migration of $B$ and other cells (Cagigi et al., 2008). Surprisingly B cells also produce CXCL13 during HIV-1 infection. It is interesting to speculate on the possibility that increased production of CXCL13 from B cells may affect the follicular localization of Tfh cells, a process mediated by up-regulation of CXCR5 receptor on Tfh cells (Haynes et al., 2007).

\section{PD-1 BLOCKADE MAY LEAD TO INCREASE PRODUCTION OF ANTIBODIES TO PATHOGENS AND VACCINES}

The depletion of activated memory B cells in blood of SIV-infected macaques progressing rapidly to AIDS-associated conditions was associated with lack of development of SIV-specific Ab responses, reduction of non-SIV-specific antibody levels, and appearance of intestinal bacterial infections (Titanji et al., 2010). Titanji et al. (2010) suggested that PD-1 expression on B cells may play an important role in regulating the survival of activated memory $\mathrm{B}$ cells since in vitro blockade of PD-1 improved the survival of activated memory B cells and in vivo trials in SIV-infected monkeys showed that PD-1 blockade enhanced antibody responses to SIV and other microbial pathogens. Although the molecular interactions of $\mathrm{PD}-1$ present on $\mathrm{B}$ cells with $\mathrm{PD}-1$ ligands present on either $\mathrm{T}$ or $\mathrm{B}$ cells need further characterization, the results presented by Velu and Titanji pave the way for new therapy intervention during HIV infection based on PD-1 blockade (Velu et al., 2009; Titanji et al., 2010).

Molecular contact between PD-1 on T cells with PD-1 ligands on $\mathrm{B}$ cells was shown to positively affect antibody production through quality regulation of GC reactions and long-lived PC formation (Good-Jacobson et al., 2010). Apoptosis of B cells increased in GCs in the absence of PD-1 signals resulting in the formation of lower numbers of long-lived PCs. Interestingly, a recent paper 


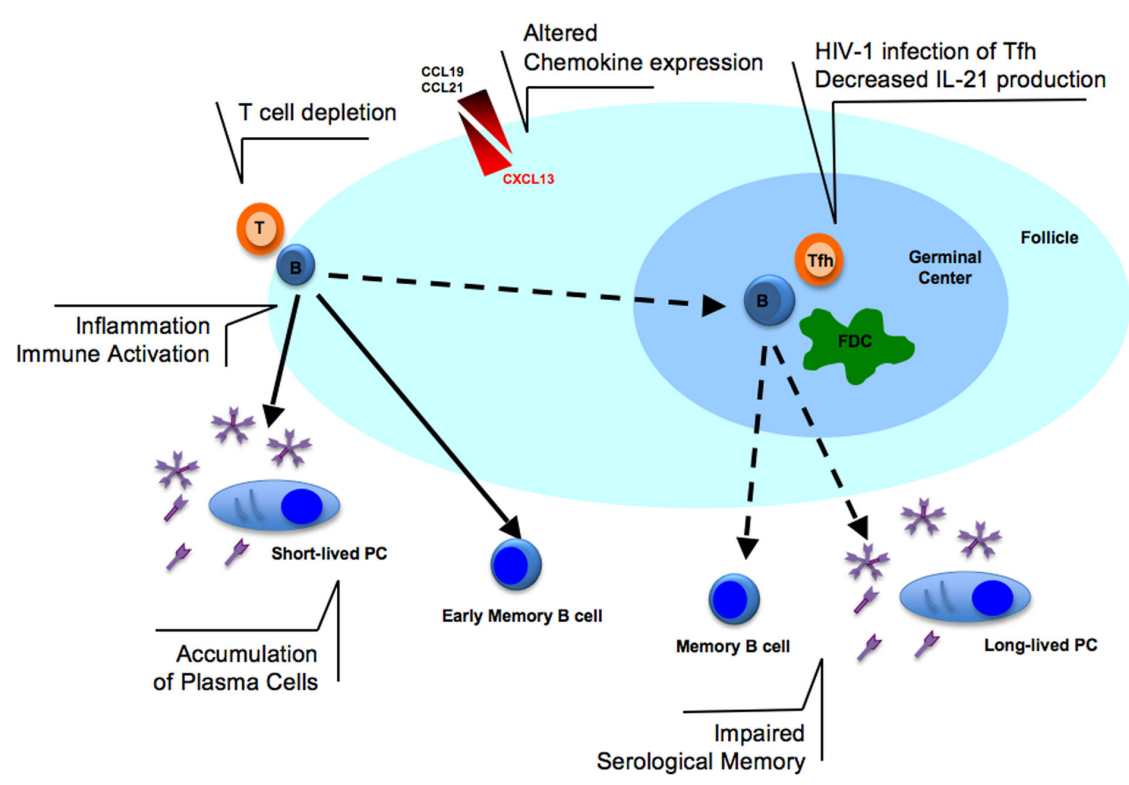

FIGURE 1 | Alterations in B cell activation in lymphoid tissues during HIV-1 infection. The T cell depletion observed in lymphoid tissues could prevent efficient $\mathrm{B}$ cell activation at the border of $\mathrm{T}$ - and $\mathrm{B}$-cell zones. The infection of T follicular helper (Tfh) cells with HIV-1 may contribute to decreased IL-21 production and, together with altered expression of chemokines (CCL19/21 and CXCL13), may further enhance the lack of germinal center (GC) formation. Follicular dendritic cells (FDC) network is also reduced during HIV-1 infection. The consequence of these dysfunctions may ultimately result in the impaired serological memory observed in HIV-1 infected patients. In addition, immune activation and inflammation, pathogenic features of HIV-1 infection, may contribute to B cell polyclonal activation and accumulation of plasma cells in lymphoid tissues possibly contributing to hypergammaglobulinemia found in serum of infected patients. showed that a population of Foxp3+Blimp-1+CD4+ T cells may be crucial to control the germinal center response (Linterman et al., 2011). These follicular regulatory $\mathrm{T}$ cells were shown to be a distinct $\mathrm{T}$ cell population sharing phenotypic characteristics with both Tfh cells and conventional Foxp3+ regulatory $\mathrm{T}$ cells, to be suppressive in vitro and to limit the number of Tfh and GC B cells. Interestingly, in the absence of Foxp3+Blimp-1+CD4+ T cells fewer antigen-specific B cells were found in GCs due to an expansion of non-antigen-specific B cells.

The PD-1 blockade trials conducted in the SIV-infected macaques and the new exciting information on PD-1 role in controlling GCs may fuel research and intervention to improve production of pathogen specific antibody responses in HIV-1 infection.

\section{ALTERATION OF IL-21 PRODUCTION}

Secreted by Tfh cells in the lymphoid tissue, IL-21 has a crucial role in GC formation (Bessa et al., 2010; Zotos et al., 2010) and induction of B cell differentiation toward PCs from both naïve and memory B cells (Ettinger et al., 2008). Interestingly, while IL-21 deficiency in mice does not impair early memory B cell responses (Linterman et al., 2010), its presence is important for secondary immune responses (Rankin et al., 2011). Extra-follicular B cell responses appear to be IL-21 independent (Linterman et al., 2010). In humans, IL-21 pathway is involved in long-lived antibody responses (Avery et al., 2010). Impairment of IL-21 receptor signaling occurs in B cells from individuals with STAT-3 deficiency, leading to a marked decreased of memory B cell formation. IL-21 was also shown to induce the expression of activation-induced cytidine deaminase and class-switch recombination (Ettinger et al., 2005).

Serum IL-21 levels are decreased in HIV-1 infected patients and a correlation was found between IL-21 levels and CD4+ T cell counts (Iannello et al., 2008, 2010). Additionally, IL-21 production by CD4+ T cells from HIV-1 infected patients has been associated with a relative control of viral load (Yue et al., 2010). It would be of great interest to study the impact of HIV-1 infection on IL-21 production from Tfh as these studies could give a crucial insight on IL-21 level in lymphoid tissues and its impact on B cells. It is likely that administration of IL-21 would beneficially impact on the generation of PCs during HIV-1 infection. Indeed, it was recently shown that IL-21 administration during SIV-infection leads to higher levels of SIV-antibody and memory B cells (Pallikkuth et al., 2011).

\section{HYPERGAMMAGLOBULINEMIA: THE ROLE OF INFLAMMATION}

The mechanisms leading to abnormal B cell activation and high immunoglobulin levels observed in patients are not conclusively established. In this part, we will focus on the role of immune activation as a possible mechanism leading to hypergammaglobulinemia.

\section{INFLAMMATION AS RESULT OF MICROBIAL TRANSLOCATION OCCURRING AT THE DAMAGED EPITHELIAL BARRIER IN THE GUT DURING HIV-1 INFECTION}

The gut-associated lymphoid tissue (GALT) is a site for HIV1 replication during the acute and chronic stages of HIV-1 
infection (Mehandru et al., 2004). It was reported that pronounced SIV replication in resting memory $\mathrm{T}$ cells in the gut leads to depletion of $\mathrm{CD} 4+\mathrm{T}$ cells in the lamina propria through a Fas-Fas ligand dependent mechanism (Li et al., 2005). Damage to the gastrointestinal tract during HIV-1 infection also results in microbial translocation (Brenchley et al., 2006). Microbial products such as lipopolysaccharide, peptidoglycan, and bacterial CpG DNA, can directly stimulate the innate immune system through toll-like receptors. Epithelial and supportive cells at the gut barrier are important regulators of the immune environment; CD4 $+\mathrm{T}$ cell depletion, especially of Th17 cells, has been linked to disruption of the epithelium (Dandekar et al., 2010). Additionally IL-1 $\beta$, interferon (IFN)$\gamma$, and tumor necrosis factor (TNF) expression was significantly increased in GALT during primary HIV-1 infection (Nilsson et al., 2007). The dysregulated levels of these cytokines in the gut is likely due to translocation of microbial components through the gut epithelium (Brenchley et al., 2006) which stimulate macrophages.

\section{THE IMPACT OF INFLAMMATORY CYTOKINES ON THE EXPRESSION OF SURVIVAL FACTORS FOR B CELLS AND PLASMA CELLS}

It is unclear how the inflammatory environment established during HIV-1 infection may contribute to changes in the expression of cytokines and factors produced from stromal cells present in lymphoid tissue.

Plasma cells reside in the BM next to reticular stromal cells, which form a survival niche and ensure their long-term survival (Tokoyoda et al., 2010). In the special microenvironment provided by reticular stromal cells, PCs produce a large amount of antibodies. PC maintenance in BM niches is under control of survival factors produced from stromal cells which are not yet completely defined, but include CXCL12, IL-4, IL-5, IL-6, IL-10, IL-21, the member of TNF family BAFF (B cell Activation Factor) and APRIL (Apoptosis-inducing ligand), and the adhesion molecules ICAM-1 and VCAM-1 (Tokoyoda et al., 2010; Chu et al., 2011).

We cultured stromal cells in the presence of IL- $1 \beta$ and IFN- $\gamma$, important molecules involved in inflammation; the gene profiles of stromal cells cultured upon these conditions (as described in Thang et al., 2010) were obtained and the results analyzed. Interestingly, the stromal cell expression of several of the factors important for the survival of PCs is altered after exposure to IL- $1 \beta$ and IFN- $\gamma$ (Table 1). For some of the factors, including IL-6, BAFF, ICAM1 , and VCAM-1 the gene expression was up-regulated more than 10 times. These results suggest that inflammation may lead to a profound deregulation of expression of survival factors for PCs.

\section{INCREASED BAFF AND HYPERGAMMAGLOBULINEMIA}

BAFF helps B cells to mature and subsequently ensures their survival (Brink, 2006; Kalled, 2006). BAFF is produced by macrophages, dendritic cells, stromal cells, and activated B and T cells (Kalled, 2006; Mackay and Leung, 2006).

BAFF levels are elevated in HIV-1 infected patients (Stohl et al., 2002; Rodriguez et al., 2003; Fontaine et al., 2011). When following patients from primary HIV-1 infection, BAFF levels were shown to be elevated, in association with increased levels of APRIL, IL-6, and IL-10 in both rapid and normal HIV-progressors from acute
Table 1 | Gene expression of factors relevant to plasma cell survival which are produced from stromal cells exposed to IL-1 $\beta$ and IFN- $\gamma$.

\begin{tabular}{lccl}
\hline & IL-1 $\beta$ & IFN- $\boldsymbol{\gamma}$ & IL-1 $\boldsymbol{\beta}+$ IFN- $\boldsymbol{\gamma}$ \\
\hline CXCL12 & $-\mathbf{1 , 6 4 *}$ & 1,06 & $-1,21$ \\
IL-4 & $-1,11$ & $-\mathbf{1 , 5 1 *}$ & $-\mathbf{1 , 5 3 *}$ \\
IL-5 & 1,02 & $-\mathbf{2 , 1 0 *}$ & $-\mathbf{2 , 3 5 * *}$ \\
IL-6 & $\mathbf{2 3 , 4 4 * *}$ & $\mathbf{2 , 9 9 * *}$ & $\mathbf{2 6 , 2 9 * *}$ \\
IL-10 & $-1,12$ & $-1,09$ & $-1,09$ \\
IL-21 & $-1,10$ & 1,04 & 1,11 \\
APRIL & $-1,18$ & 1,01 & $-1,05$ \\
BAFF & 1,16 & $\mathbf{1 5 , 3 1 * *}$ & $\mathbf{1 2 , 8 9 * *}$ \\
ICAM-1 & $\mathbf{1 1 , 2 5 * *}$ & $\mathbf{1 0 , 6 2 * *}$ & $\mathbf{4 3 , 9 3 * *}$ \\
VCAM-1 & $\mathbf{3 , 1 8 *}$ & 1,28 & $\mathbf{3 2 , 1 5 * *}$ \\
\hline
\end{tabular}

The gene expression profiles of factors relevant to plasma cell survivals changed upon treatment of HS27 stromal cells for $6 \mathrm{~h}$ with IL-1 3 and/or IFN- $\gamma$, as compared to control cells without stimulation. The numbers in the table indicate the fold increase in expression levels in the treatment groups versus the control group. The text in bold indicate significant changes. ${ }^{*} p<0.05 ;{ }^{*} p<0.005$. The methods and conditions were previously published (Thang et al., 2010). Briefly, total RNA was harvested from the HS27 cell line at $6 \mathrm{~h}$ after stimulation with either IL-13 or IFN- $\gamma$ or the combination of both cytokines; non-stimulated cells (three independent cultures for each condition) were used as source for control RNA. Labeled cDNA was prepared according to standard Affymetrix protocol and hybridized to the whole-genome microarray Human Gene 1.0 ST (Affymetrix, Inc., Santa Clara, CA, USA), according to standard Affymetrix protocols. Image analysis was performed using Affymetrix Command Console (AGCC) v 1.1, and the down-stream processing in Affymetrix Expression Console (EC) $\vee$ 1.1.

infection into the chronic phase of infection (Fontaine et al., 2011). BAFF expression remains altered in spite of successful ART; however in aviremic slow progressors BAFF levels were comparable to what found in healthy donors. Patients with lower CD4+ T cell counts display higher BAFF and total IgG levels, suggesting a role for BAFF in hypergammaglobulinemia (Rodriguez et al., 2003). In fact, elevated BAFF levels have been linked with increased Tindependent $\mathrm{B}$ cell activation and isotype switching in mice models (Mackay and Schneider, 2009). BAFF can also lead to mannose Ctype lectin receptor up-regulation on B cells, facilitating for HIV-1 protein gp120 binding and thus participating in polyclonal B cell activation occurring in extra-follicular zone of lymphoid tissue (He et al., 2006).

It can be questioned whether high level of BAFF results from the pathological immune activation present during HIV-1 infection in response to the inflammatory milieu created by the virus in lymphoid tissues, including the gut. In support of this hypothesis it was recently shown that monocytes from patients with systemic lupus erythematosus produced significantly larger amounts of BAFF in response to IFN $-\gamma$ as compared to healthy controls (Harigai et al., 2008). It should be further investigated whether this pathological feature is in common between patients with systemic lupus erythematosus and HIV-1. BAFF was shown to increase the chemotactic response of memory B cells toward CXCL13 (Badr et al., 2008). It is yet not studied whether high levels of CXCL13 (Cagigi et al., 2008) and BAFF may synergize to affect GC formation. 


\section{CONCLUSION}

In summary fibrosis and the altered chemokine and cytokine levels in lymphoid tissues, together with $\mathrm{T}$ cell depletion could explain some of the impairments of serological memory occurring in HIV-1 infected patients. Microbial translocation and inflammation, which have been previously involved in $\mathrm{T}$ cell hyperactivation and depletion, may be important factors in the deregulated expression of molecule and pathways involved in B cell differentiation.

Cellular and molecular studies are essential to pin-point the exact mechanisms of damaged GC formation during HIV-1 infection. Many relevant studies recently provided new insights on molecular players and mechanisms relevant for the GC reaction and regulation of memory B cell maintenance upon physiological conditions. These studies may be inspiring and pivotal for understanding pathogenic mechanisms during HIV-1 infection and

\section{REFERENCES}

Alos, L., Navarrete, P., Morente, V., Garcia, F., Garrido, M., Plana, M., Mozos, A., Lopez, A., Gil, C., Pumarola, T., Caballero, M., Blanch, J. L., Fumero, E., Miro, J. M., Gallart, T., Gatell, J. M., and Campo, E. (2005). Immunoarchitecture of lymphoid tissue in HIV-infection during antiretroviral therapy correlates with viral persistence. Mod. Pathol. 18, 127-136.

Avery, D. T., Deenick, E. K., Ma, C. S., Suryani, S., Simpson, N., Chew, G. Y., Chan, T. D., Palendira, U., Bustamante, J., Boisson-Dupuis, S., Choo, S., Bleasel, K. E., Peake, J., King, C., French, M. A., Engelhard, D., Al-Hajjar, S., Al-Muhsen, S., Magdorf, K., Roesler, J., Arkwright, P. D., Hissaria, P., Riminton, D. S., Wong, M., Brink, R., Fulcher, D. A., Casanova, J. L., Cook, M. C., and Tangye, S. G. (2010). B cell-intrinsic signaling through IL-21 receptor and STAT3 is required for establishing long-lived antibody responses in humans. J. Exp. Med. 207, 155-171.

Badr, G., Borhis, G., Lefevre, E. A., Chaoul, N., Deshayes, F., Dessirier, V., Lapree, G., Tsapis, A., and Richard, Y. (2008). BAFF enhances chemotaxis of primary human $\mathrm{B}$ cells: a particular synergy between BAFF and CXCL13 on memory B cells. Blood 111, 2744-2754.

Berkowska, M. A., Driessen, G. J., Bikos, V., Grosserichter-Wagener, C., Stamatopoulos, K., Cerutti, A., He, B., Biermann, K., Lange, J. F., Van Der Burg, M., Van Dongen, J. J., and Van Zelm, M. C. (2011). Human memory B cells originate from three distinct germinal center-dependent and -independent maturation pathways. Blood 118, 2150-2158.
Bessa, J., Kopf, M., and Bachmann, M. F. (2010). Cutting edge: IL-21 and TLR signaling regulate germinal center responses in a B cellintrinsic manner. J. Immunol. 184, 4615-4619.

Brenchley, J. M., Price, D. A., Schacker, T. W., Asher, T. E., Silvestri, G., Rao, S., Kazzaz, Z., Bornstein, E., Lambotte, O., Altmann, D., Blazar, B. R., Rodriguez, B., Teixeira-Johnson, L., Landay, A., Martin, J. N., Hecht, F. M., Picker, L. J., Lederman, M. M., Deeks, S. G., and Douek, D. C. (2006). Microbial translocation is a cause of systemic immune activation in chronic HIV infection. Nat. Med. 12, 1365-1371.

Brink, R. (2006). Regulation of B cell self-tolerance by BAFF. Semin. Immunol. 18, 276-283.

Cagigi, A., Mowafi, F., Phuong Dang, L. V., Tenner-Racz, K., Atlas, A., Grutzmeier, S., Racz, P., Chiodi, F., and Nilsson, A. (2008). Altered expression of the receptor-ligand ing chronic HIV-1 infection. Blood 112, 4401-4410.

Cagigi, A., Nilsson, A., Pensieroso, S., and Chiodi, F. (2010). Dysfunctional B-cell responses during HIV-1 infection: implication for influenza vaccination and highly active antiretroviral therapy. Lancet Infect. Dis. 10, 499-503.

Chiodi, F. (2010). New therapy to revert dysfunctional antibody responses during HIV-1 infection. J. Clin. Invest. 120, 3810-3813.

Chu, V. T., Beller, A., Nguyen, T. T., Steinhauser, G., and Berek, C. (2011). The long-term survival of plasma cells. Scand. J. Immunol. 73, 508-511.

Dandekar, S., George, M. D., and Baumler, A. J. (2010). Th17 cells, HIV and pair CXCR5/CXCL13 in B cells dur-

may lead to new potential targets for improving immunological responses.

Additionally, studies of pathogenic and non-pathogenic SIVinfection, distinguished by different levels of immune activation, could contribute key knowledge on B cell dysfunctions occurring during HIV-1 infection.

\section{ACKNOWLEDGMENTS}

The work of the authors is supported by grants received from the Swedish MRC, the Swedish International Development Agency (SIDA-SAREC), the EU Fp7 Collaborative project NGIN (HealthF3-2007-201433), the Fp6 Network of Excellence Europrise, and the Karolinska Institutet. Financial support was also provided through the regional agreement on medical training and clinical research (ALF) between Stockholm County Council and the Karolinska Institutet.

the gut mucosal barrier. Curr. Opin. HIV AIDS 5, 173-178.

Estes, J. D., Haase, A. T., and Schacker, T. W. (2008). The role of collagen deposition in depleting CD4+ T cells and limiting reconstitution in HIV-1 and SIV infections through damage to the secondary lymphoid organ niche. Semin. Immunol. 20, 181-186.

Ettinger, R., Kuchen, S., and Lipsky, P. E. (2008). The role of IL-21 in regulating B-cell function in health and disease. Immunol. Rev. 223, 60-86.

Ettinger, R., Sims, G. P., Fairhurst, A. M., Robbins, R., Da Silva, Y. S., Spolski, R., Leonard, W. J., and Lipsky, P. E. (2005). IL-21 induces differentiation of human naive and memory B cells into antibody-secreting plasma cells. J. Immunol. 175, 7867-7879.

Fontaine, J., Chagnon-Choquet, J., Valcke, H. S., Poudrier, J., and Roger, M. (2011). High expression levels of B lymphocyte stimulator (BLyS) by dendritic cells correlate with HIVrelated B-cell disease progression in humans. Blood 117, 145-155.

Geretti, A. M., and Doyle, T. (2010). Immunization for HIV-positive individuals. Curr. Opin. Infect. Dis. 23, 32-38.

Good-Jacobson, K. L., Szumilas, C. G., Chen, L., Sharpe, A. H., Tomayko, M. M., and Shlomchik, M. J. (2010). PD-1 regulates germinal center $\mathrm{B}$ cell survival and the formation and affinity of long-lived plasma cells. Nat. Immunol. 11, 535-542.

Harigai, M., Kawamoto, M., Hara, M., Kubota, T., Kamatani, N., and Miyasaka, N. (2008). Excessive production of IFN-gamma in patients with systemic lupus erythematosus and its contribution to induction of B lymphocyte stimulator/B cell-activating factor/TNF ligand superfamily-13B. J. Immunol. 181, 2211-2219.

Haynes, N. M., Allen, C. D., Lesley, R., Ansel, K. M., Killeen, N., and Cyster, J. G. (2007). Role of CXCR5 and CCR7 in follicular Th cell positioning and appearance of a programmed cell death gene-1high germinal center-associated subpopulation. J. Immunol. 179, 5099-5108.

He, B., Qiao, X., Klasse, P. J., Chiu, A., Chadburn, A., Knowles, D. M., Moore, J. P., and Cerutti, A. (2006). HIV-1 envelope triggers polyclonal Ig class switch recombination through a CD40independent mechanism involving BAFF and C-type lectin receptors. J. Immunol. 176, 3931-3941.

Ho, J., Moir, S., Wang, W., Posada, J. G., Gu, W., Rehman, M. T., Dewar, R., Kovacs, C., Sneller, M. C., Chun, T. W., Follmann, D. A., and Fauci, A. S. (2011). Enhancing effects of adjuvanted 2009 pandemic H1N1 influenza $A$ vaccine on memory $B-$ cell responses in HIV-infected individuals. AIDS 25, 295-302.

Huang, K. H., Bonsall, D., Katzourakis, A., Thomson, E. C., Fidler, S. J., Main, J., Muir, D., Weber, J. N., Frater, A. J., Phillips, R. E., Pybus, O. G., Goulder, P. J., Mcclure, M. O., Cooke, G. S., and Klenerman, P. (2010). B-cell depletion reveals a role for antibodies in the control of chronic HIV-1 infection. Nat. Commun. 1, 102

Iannello, A., Boulassel, M. R., Samarani, S., Debbeche, O., Tremblay, C., Toma, E., Routy, J. P., and Ahmad, A. (2010). Dynamics and consequences of IL-21 production in HIV-infected individuals: a longitudinal and crosssectional study. J. Immunol. 184, 114-126. 
Iannello, A., Tremblay, C., Routy, J. P., Boulassel, M. R., Toma, E., and Ahmad, A. (2008). Decreased levels of circulating IL-21 in HIVinfected AIDS patients: correlation with CD4+ T-cell counts. Viral Immunol. 21, 385-388.

Kalled, S. L. (2006). Impact of the BAFF/BR3 axis on B cell survival, germinal center maintenance and antibody production. Semin. Immunol. 18, 290-296.

Klatt, N. R., Vinton, C. L., Lynch, R. M., Canary, L. A., Ho, J., Darrah, P. A., Estes, J. D., Seder, R. A., Moir, S. L., and Brenchley, J. M. (2011). SIV infection of rhesus macaques results in dysfunctional T- and B-cell responses to neo and recall Leishmania major vaccination. Blood 118 , 5803-5812.

Lane, H. C., Masur, H., Edgar, L. C., Whalen, G., Rook, A. H., and Fauci, A. S. (1983). Abnormalities of B-cell activation and immunoregulation in patients with the acquired immunodeficiency syndrome. N. Engl. J. Med. 309, 453-458.

Lanzavecchia, A., and Sallusto, F. (2009). Human B cell memory. Curr. Opin. Immunol. 21, 298-304.

Lederman, M. M., and Margolis, L. (2008). The lymph node in HIV pathogenesis. Semin. Immunol. 20, 187-195.

Lewis, G. K. (2010). Challenges of antibody-mediated protection against HIV-1. Expert Rev. Vaccines 9, 683-687.

Li, Q., Duan, L., Estes, J. D., Ma, Z. M., Rourke, T., Wang, Y., Reilly, C., Carlis, J., Miller, C. J., and Haase, A. T. (2005). Peak SIV replication in resting memory $\mathrm{CD} 4+\mathrm{T}$ cells depletes gut lamina propria $\mathrm{CD} 4+\mathrm{T}$ cells. Nature 434, 1148-1152.

Linterman, M. A., Beaton, L., Yu, D., Ramiscal, R. R., Srivastava, M., Hogan, J. J., Verma, N. K., Smyth, M. J., Rigby, R. J., and Vinuesa, C. G. (2010). IL-21 acts directly on B cells to regulate $\mathrm{Bcl}-6$ expression and germinal center responses. J. Exp. Med. 207, 353-363.

Linterman, M. A., Pierson, W., Lee, S. K., Kallies, A., Kawamoto, S., Rayner, T. F., Srivastava, M., Divekar, D. P., Beaton, L., Hogan, J. J., Fagarasan, S., Liston, A., Smith, K. G., and Vinuesa, C. G. (2011). Foxp3+ follicular regulatory $\mathrm{T}$ cells control the germinal center response. Nat. Med. 17, 975-982.

Macias, J., Japon, M. A., Leal, M., Saez, C., Pineda, J. A., Segura, D. I., Ortega, J., and Lissen, E. (2001). Structural normalization of the lymphoid tissue in asymptomatic HIV-infected patients after 48 weeks of potent antiretroviral therapy. AIDS 15, 2371-2378.

Mackay, F., and Leung, H. (2006). The role of the BAFF/APRIL system on $\mathrm{T}$ cell function. Semin. Immunol. 18, 284-289.

Mackay, F., and Schneider, P. (2009). Cracking the BAFF code. Nat. Rev Immunol. 9, 491-502.

Mascola, J. R., and Montefiori, D. C. (2010). The role of antibodies in HIV vaccines. Annu. Rev. Immunol. $28,413-444$.

Mehandru, S., Poles, M. A., TennerRacz, K., Horowitz, A., Hurley, A. Hogan, C., Boden, D., Racz, P., and Markowitz, M. (2004). Primary HIV-1 infection is associated with preferential depletion of $\mathrm{CD} 4+\mathrm{T}$ lymphocytes from effector sites in the gastrointestinal tract. J. Exp. Med. 200, 761-770.

Miedema, F. (2011). Grand challenges in the immunology of HIV and AIDS. Front. Immunol. 2:20. doi:10.3389/fimmu.2011.00020

Moir, S., Ho, J., Malaspina, A., Wang, W., Dipoto, A. C., O'Shea, M. A., Roby, G., Kottilil, S., Arthos, J., Proschan, M. A., Chun, T. W., and Fauci, A. S. (2008). Evidence for HIV-associated $B$ cell exhaustion in a dysfunctional memory B cell compartment in HIV-infected viremic individuals. J. Exp. Med. 205, 1797-1805.

Moir, S., Malaspina, A., Ogwaro, K. M., Donoghue, E. T., Hallahan, C. W., Ehler, L. A., Liu, S., Adelsberger, J., Lapointe, R., Hwu, P., Baseler, M., Orenstein, J. M., Chun, T. W., Mican, J. A., and Fauci, A. S. (2001). HIV-1 induces phenotypic and functional perturbations of B cells in chronically infected individuals. Proc. Natl. Acad. Sci. U.S.A. 98, 10362-10367.

Muro-Cacho, C. A., Pantaleo, G., and Fauci, A. S. (1995). Analysis of apoptosis in lymph nodes of HIV-infected persons. Intensity of apoptosis correlates with the general state of activation of the lymphoid tissue and not with stage of disease or viral burden. J. Immunol. 154, 5555-5566.

Nilsson, J., Kinloch-De-Loes, S. Granath, A., Sonnerborg, A., Goh, L. E., and Andersson, J. (2007). Early immune activation in gutassociated and peripheral lymphoid tissue during acute HIV infection. AIDS 21, 565-574.

Nutt, S. L., and Tarlinton, D. M. (2011). Germinal center B and follicular helper $\mathrm{T}$ cells: siblings, cousins or just good friends? Nat. Immunol. 12, 472-477.

Pallikkuth, S., Rogers, K., Villinger, F., Dosterii, M., Vaccari, M., Franchini,
G., Pahwa, R., and Pahwa, S. (2011). Interleukin-21 administration to rhesus macaques chronically infected with simian immunodeficiency virus increases cytotoxic effector molecules in T cells and NK cells and enhances B cell function without increasing immune activation or viral replication. Vaccine 29, 9229-9238.

Pariani, E., Boschini, A., Amendola, A., Poletti, R., Anselmi, G., Begnini, M., Ranghiero, A., Cecconi, G. and Zanetti, A. R. (2011). Response to 2009 pandemic and seasonal influenza vaccines co-administered to HIV-infected and HIV-uninfected former drug users living in a rehabilitation community in Italy. Vaccine 29, 9209-9213.

Pelletier, N., Mcheyzer-Williams, L. J., Wong, K. A., Urich, E., Fazilleau, N., and Mcheyzer-Williams, M. G. (2010). Plasma cells negatively regulate the follicular helper $\mathrm{T}$ cell program. Nat. Immunol. 11, 1110-1118.

Qiao, X., He, B., Chiu, A., Knowles, D. M., Chadburn, A., and Cerutti, A. (2006). Human immunodeficiency virus 1 Nef suppresses CD40dependent immunoglobulin class switching in bystander B cells. Nat. Immunol. 7, 302-310.

Rankin, A. L., Macleod, H., Keegan, S., Andreyeva, T., Lowe, L., Bloom, L. Collins, M., Nickerson-Nutter, C., Young, D., and Guay, H. (2011). IL21 receptor is critical for the development of memory B cell responses. J. Immunol. 186, 667-674.

Rodriguez, B., Valdez, H., Freimuth, W. Butler, T., Asaad, R., and Lederman, M. M. (2003). Plasma levels of Blymphocyte stimulator increase with HIV disease progression. AIDS 17, 1983-1985.

Samuelsson, A., Sonnerborg, A., Heuts, N., Coster, J., and Chiodi, F. (1997). Progressive B cell apoptosis and expression of Fas ligand during human immunodeficiency virus type 1 infection. AIDS Res. Hum. Retroviruses 13, 1031-1038.

Scheid, J. F., Mouquet, H., Feldhahn, N., Seaman, M. S., Velinzon, K., Pietzsch, J., Ott, R. G., Anthony, R. M. Zebroski, H., Hurley, A., Phogat, A., Chakrabarti, B., Li, Y., Connors, M., Pereyra, F., Walker, B. D., Wardemann, H., Ho, D., Wyatt, R. T., Mascola, J. R., Ravetch, J. V., and Nussenzweig, M. C. (2009). Broad diversity of neutralizing antibodies isolated from memory B cells in HIV-infected individuals. Nature 458, 636-640.

Stohl, W., Cheema, G. S., Briggs, W. S., Xu, D., Sosnovtseva, S., Roschke,
V., Ferrara, D. E., Labat, K., Sattler, F. R., Pierangeli, S. S., and Hilbert, D. M. (2002). B lymphocyte stimulator protein-associated increase in circulating autoantibody levels may require $\mathrm{CD} 4+\mathrm{T}$ cells: lessons from HIV-infected patients. Clin. Immunol. 104, 115-122.

Swingler, S., Zhou, J., Swingler, C., Dauphin, A., Greenough, T., Jolicoeur, P., and Stevenson, M. (2008). Evidence for a pathogenic determinant in HIV-1 Nef involved in B cell dysfunction in HIV/AIDS. Cell Host Microbe 4, 63-76.

Thang, P. H., Ruffin, N., Brodin, D., Rethi, B., Cam, P. D., Hien, N. T., Lopalco, L., Vivar, N., and Chiodi, F. (2010). The role of IL-1beta in reduced IL-7 production by stromal and epithelial cells: a model for impaired T-cell numbers in the gut during HIV-1 infection. J. Intern. Med. 268, 181-193.

Titanji, K., De Milito, A., Cagigi, A., Thorstensson, R., Grutzmeier, S., Atlas, A., Hejdeman, B., Kroon, F. P., Lopalco, L., Nilsson, A., and Chiodi, F. (2006). Loss of memory B cells impairs maintenance of longterm serologic memory during HIV1 infection. Blood 108, 1580-1587.

Titanji, K., Velu, V., Chennareddi, L., Vijay-Kumar, M., Gewirtz, A. T., Freeman, G. J., and Amara, R. R. (2010). Acute depletion of activated memory B cells involves the PD-1 pathway in rapidly progressing SIVinfected macaques. J. Clin. Invest. $120,3878-3890$.

Tokoyoda, K., Hauser, A. E., Nakayama, T., and Radbruch, A. (2010). Organization of immunological memory by bone marrow stroma. Nat. Rev Immunol. 10, 193-200.

Van Grevenynghe, J., Halwani, R., Chomont, N., Ancuta, P., Peretz, Y., Tanel, A., Procopio, F. A., Shi, Y., Said, E. A., Haddad, E. K., and Sekaly, R. P. (2008). Lymph node architecture collapse and consequent modulation of FOXO3a pathway on memory $\mathrm{T}$ - and B-cells during HIV infection. Semin. Immunol. 20 , 196-203.

Velu, V., Titanji, K., Zhu, B., Husain, S., Pladevega, A., Lai, L., Vanderford, T. H., Chennareddi, L., Silvestri, G., Freeman, G. J., Ahmed, R., and Amara, R. R. (2009). Enhancing SIVspecific immunity in vivo by PD-1 blockade. Nature 458, 206-210.

Yue, F. Y., Lo, C., Sakhdari, A., Lee, E. Y., Kovacs, C. M., Benko, E., Liu, J., Song, H., Jones, R. B., Sheth, P., Chege, D., Kaul, R., and Ostrowski, M. A. (2010). HIV-specific IL21 producing $\mathrm{CD} 4+\mathrm{T}$ cells are 
induced in acute and chronic progressive HIV infection and are associated with relative viral control. $J$. Immunol. 185, 498-506.

Zeng, M., Smith, A. J., Wietgrefe, S. W., Southern, P. J., Schacker, T. W., Reilly, C. S., Estes, J. D., Burton, G. F., Silvestri, G., Lifson, J. D., Carlis, J. V., and Haase, A. T. (2011). Cumulative mechanisms of lymphoid tissue fibrosis and $\mathrm{T}$ cell depletion in HIV1 and SIV infections. J. Clin. Invest. 121, 998-1008.
Zotos, D., Coquet, J. M., Zhang, Y., Light, A., D'Costa, K., Kallies, A., Corcoran, L. M., Godfrey, D. I., Toellner, K. M., Smyth, M. J., Nutt, S. L., and Tarlinton, D. M. (2010). IL-21 regulates germinal center $B$ cell differentiation and proliferation through a $\mathrm{B}$ cellintrinsic mechanism. J. Exp. Med. 207, 365-378.

Conflict of Interest Statement: The authors declare that the research was conducted in the absence of any commercial or financial relationships that could be construed as a potential conflict of interest.

Received: 13 November 2011; accepted: 19 December 2011; published online: 05 January 2012.

Citation: Ruffin N, Thang PH, Rethi B, Nilsson A and Chiodi F (2012) The impact of inflammation and immune activation on $B$ cell differentiation during HIV-1 infection. Front. Immun. 2:90. doi: 10.3389/fimmu.2011.00090
This article was submitted to Frontiers in HIV and AIDS, a specialty of Frontiers in Immunology.

Copyright (๑) 2012 Ruffin, Thang, Rethi, Nilsson and Chiodi. This is an open-access article distributed under the terms of the Creative Commons Attribution Non Commercial License, which permits non-commercial use, distribution, and reproduction in other forums, provided the original authors and source are credited. 